\title{
The Earth Under Your Feet (Zem pod nohami)
}

\author{
Author: Mikuláš Kováč
}

First Published: 1960

About the Author: Mikuláš Kováč (1934-1992) was a Slovak poet, playwright and author of children's books. He graduated from High School for Industrial Studies in Zvolen in Central Slovakia (1953) and studied pedagogy at Comenius University in Bratislava. He did not finish his studies for health reasons. Kováč spent almost his whole life in Banská Bystrica in Central Slovakia where he worked as a local government official, a manager in the puppet theatre, a journalist in newspapers and for Slovakian radio. He participated in writing the script of the film Build a House, Plant a Tree (1979, Postav dom, zasad' strom) directed by Juraj Jakubisko. From 1980 he drew social security benefits for being on disability.

Further Important Publications: Rozmery (1964, Dimensions; poems); Návraty (1966, Returns; poem), O modrej labuti (1966, About a Blue Swan; poems); Vybrané verše (1978, Selected Poems); Básne (1984, Poems; anthology of poems).

\section{Content and Interpretation}

The collection of poems, written in free verse, consists of three parts. The first contains nine poems, the second twelve poems, and the third one extensive poem My Town (Moje mesto) inspired by Kováč’s home city Banská Bystrica.

The main topic of the poems is the current everyday life of ordinary people confronted with the brutal reality of World War II that the author experienced as a child. So the introductory poem The Wall (Stena) first depicts the pale white wall where a man has been executed. Secondly the same expression „bledý ako stena“ (in English free translation "white as chalk") is used for someone who is sated with food today. The author comments "we have already forgotten these scenes", which means the war (Kováč, 1985, p. 11). A similar confrontation can be found in the following poem The Rose Garden (Ružová záhrada). An idyllic springtime nature with a "silver meadow" is presented here. In the meadow, the soldiers shoot the inhabitants of a village, pile their bodies in a pit and cover them with lime. In the evening, the same soldiers play music and listen to Franz Schubert's song Germany, Germany, a rose garden (p. 13). They cry and being deeply touched whisper: "The music of our master is so beautiful, so human" (p. 13).

Auschwitz and other concentration camps are directly presented in two poems, Auschwitz 1958 (Osvienčim 1958) and The Prison Compound (Dvor). Auschwitz 1958 describes the author's visit to this extermination camp. He watches the exhibition of victims' hair, their suitcases, prosthetics and lists of their names. He asks where all of these people are. The people answer they have left to blue Heaven through the black 
chimney. Therefore Heaven is full of "legless angels, / angels marked with numbers, / angels / with their teeth kicked out” (p. 26). A sarcastic author's comment follows: "Great God, / mighty and just, / these angels play the harp for you / if you're bored?" (p. 26). In the following part of this poem the victims answer the question of what they left behind. There are blankets and scrub brushes made from their hair, soap made from their bones, a big black cloud from which it still rains and a bird who has drunk their blood and sings in their voice. The poem Auschwitz 1958 was set to music by Ilja Zeljenka in 1959 (Auschwitz, cantata for two reciters, a mixed choir and orchestra). Six verses of the poem The Wall became a part of Eugen Suchoň's musical composition Contemplations (1964, Kontemplácie) consisting of several poems and literary works.

Also the poem The Prison Compound (Dvor) contrasts the situation in a concentration camp with current life. The death toll of the camp of four milion victims seems to point to Auschwitz again, because it was the supposed number of killed prisoners in Auschwitz at that time. The prisoners are standing in the yard where some of them are shot down by an SS officer. The "good German bullet" fired from his pistol "is still flying [...] around the world" (p. 29). And the dead prisoners envy a young modern day man who is currently standing in the yard with his girlfriend and chewing a blade of grass.

Motifs of the war and the persecution of the Jews appear again in the third part of The Earth Under Your Feet. Here, among others, the author depicts men in black uniforms and black shoes (the Slovak military Fascist organisation the Hlinka Guard) who came in a black car and took away his Jewish neighbours, Mr Štraus, his wife and their children, who were friends of the narrator (the poet). Later the same men also arrested the boy's father who had participated in the resistance. The father never came home again. He left behind his books, an empty bed, an empty room and the half empty world of his wife and the son (p. 82).

\section{Main Topics and Problems}

The Earth Under Your Feet was Mikuláš Kováč's debut book. Kováč belonged to the generation of young Slovak poets at the end of the 1950s who disagreed with the abstract, only declarative works of their predecessors in the official literature. They proclaimed to present everyday life and their own private experience in their poems. These poets also thematised the persecution of the Jews (that was marginalised in the preceding period) and the extermination camp in Auschwitz. It inspired the slightly older Ivan Kupec in his collection Seashell (1961, Mušla) and mainly Ján Ondruš in his poems The Fire in Auschwitz (Osvěnčimský oheň) as well as The Ashes in Auschwitz (Osvěnčimský popol) in the book The Egg (Vajičko) that could not be published in the late 1950s (Matejov, 2005). These poems were published later in Ondruš's book The Mad Moon (1965, Šialený mesiac).

Both Ján Ondruš and Mikuláš Kováč create limit situations in their poems to ask about the guilt and responsibility for the mass murder during the war and to remind the public of the victims and in general of the human situation. Nevertheless, cruel 
acts are depicted in a factual and sober way, without the usual pathos and direct ethical condemnation (Matejov, 2006, p. 199). Both young poets were probably inspired by the poems of the Polish author Tadeusz Różewicz whose poems The Braid (Warkoczyk) or Massacre of the Boys (Rzeź chłopców) as well as the short story $\rightarrow$ A Trip to the Museum, depict topic similar to Kováčs Auschwitz 1958. The same subject thematised the young Czech poet Petr Prouza in his poem Silence in Auschwitz in Židovská ročenka 1964.

The collection The Earth Under Your Feet caused a strong response. Reviewer Pavol Števček reproached Kováč for "aesthetical adventurism”, little life experience and indiscipline in his poetics. It provoked many reactions from young poets and critics who in most cases stood up for Kováč and his poetry. Critic and literary scientist Milan Hamada stated, polemicising with Števček, that Kováč's asking questions and his moral anxiety are more important than ideological correctness as well as virtuosity of the style (Hamada 1961 and 1966).

Mikuláš Kováš continues in his subsequent works (Dimensions, 1964; Returns, 1966) on topics and stylistic devices beginning in his debut. There are stories of ordinary men who have to endure the burden of tragic historical events, their tiny pleasures and worries (Matejov, 2019, pp. 70-71).

\section{Cited Works}

fm (= Matejov, F.) (2006). Kováč, Mikuláš: Zem pod nohami. In: R. Chmel et al., Slovník diel slovenskej literatúry 20. storočia. Bratislava: Kalligram, pp. 197-200. Hamada, M. (1961). Snaha o stopy. Slovenské pohlady, 77(4), pp. 90-92. Hamada, M. (1966). V hladaní významu a tvaru. Bratislava: Smena, pp. 32-35. Kováč, M. (1985). Zem pod nohami. 4th edition. Bratislava: Slovenský spisovatel'. Matejov F. (2005). Lektúry. Bratislava: SAP, pp. 72-73. Matejov, F. (2019). Lekcie (z) poézie. Bratislava: SAP.

\section{Further References}

Borgul'ová, J., ed. (1998). Mikuláš Kováč: Zborník materiálov $z$ vedeckej konferencie $v$ Banskej Bystrici. Banská Bystrica: Literárne a hudobné múzeum. Podhradská, M. (1985). Básnik so zemou pod nohami a nebom nad hlavou. In: M. Kováč, Zem pod nohami. Bratislava: Slovenský spisovatel', pp. 87-91. Šimon, L. (1999). Básnická prvotina Mikuláša Kováča Zem pod nohami. Literika, 4(3), pp. 97-103. Šmatlák, S. (1979). Dve storočia slovenskej lyriky: Obdobia - osobnosti - diela. Bratislava: Tatran, pp. 494500. Šmihla, Š., Balko, S. (eds.). (2000). Svedectvo o stavu ludskej duše. Koláž dokumentov a spomienok na básnika Mikuláša Kováča. Bratislava, Banská Bystrica: Literárne a hudobné muzeum. 